\title{
The Relation between Hedonic and Utilitarian Values on Satisfaction and Behavior Intention among Casual-Dining Restaurants Customers
}

\author{
Tammy Kathlia Kertasunjaya1, Tanya Diza Mediasari1, Peri Akbar Manaf2* \\ ${ }^{1}$ Master of Management in Business Management Professional Program, Bina Nusantara University, Jakarta, Indonesia \\ ${ }^{2}$ Business Management Program, Management Department, BINUS Business School, Master Program, Bina Nusantara \\ University, Jakarta, Indonesia \\ Email: tammykathlia@gmail.com, tanyadiza@gmail.com, ^pmanaf@binus.edu
}

How to cite this paper: Kertasunjaya, T. K., Mediasari, T. D., \& Manaf, P. A. (2020). The Relation between Hedonic and Utilitarian Values on Satisfaction and Behavior Intention among Casual-Dining Restaurants Customers. Open Journal of Business and Management, 8, 2480-2492.

https://doi.org/10.4236/ojbm.2020.86154

Received: August 29, 2020

Accepted: November 14, 2020

Published: November 17, 2020

Copyright $\odot 2020$ by author(s) and Scientific Research Publishing Inc. This work is licensed under the Creative Commons Attribution International License (CC BY 4.0).

http://creativecommons.org/licenses/by/4.0/

\begin{abstract}
As the third largest population country, Indonesia had millennials as their biggest spender than baby boomers. The millennials allocate their income for eating at the restaurants after family expenses and savings. Meanwhile, the increasing number of casual dining restaurants in Jakarta, delivered satisfying experiences and less intimidated than fine dining but higher than fast food with affordable price. The restaurants gave them hedonic and utilitarian values that matched with the millennial behavior and lifestyles. This study intends to inspect the relationship between hedonic and utilitarian values on satisfaction and behavior intention among casual-dining customers in Jakarta. The data was collected from 150 millennials in Jakarta through a web-based survey. The respondents were informed that they would be asked about their experience in casual dining restaurants in Jakarta. Result revealed that customer satisfaction had a significant and positive relationship toward the hedonic value, customer satisfaction had a significant and positive relationship toward the utilitarian value and customer satisfaction had significant impact with positive effect toward the Behavioral Intentions. The findings of this study propose for theoretical and managerial implementations.
\end{abstract}

\section{Keywords}

Hedonic, Utilitarian, Satisfaction, Behavior Intention, Casual Dining

\section{Introduction}

Indonesia foodservices offer services and several types of restaurant such as full-service restaurant, self-service restaurant, fast food, street stall, cafe and bar, 
and home delivery restaurant (Indonesia Food Service Market, 2020). The market is expected to grow at a CAGR of $7.06 \%$ in the period of $2019-2024$ (Research and Markets ltd., 2019). To sustain in the foodservice industry, restaurants need to achieve high customer satisfaction ratings in aspects such as quality of food and services, ambience and overall dining experience (Ryu, Lee, \& Gon Kim, 2012). The experience of dining relies on a variety of variables, such as dining character, social interactions during meals, autobiographical memories, food perceptions and the atmosphere. Also it's more convenient to save time and sometimes cheaper (Díaz-Méndez \& Van Der Brock, 2017; Spence \& Piqueras-Fiszman, 2014).

Casual dining is one of the types of full-services restaurants and usually delivers satisfying experiences, less intimidated than fine dining but higher than fast food also with affordable price (Cuca, 2019). Modern food attempts to captivate the increasingly demanding taste of diners and critics also maximized both innovation and satisfaction (Muñoz et al., 2018). Customer satisfaction is described as delightful, completeness, and enjoyment for the service (Atulkar \& Kesari, 2017; Thaichon \& Quach, 2015). Yuen and Chan (2010) found that loyal customers are valuable for retailers because of the tendency of customers to purchase and willing to spend more than less loyal customers. To earn profits in a competitive market, business must strengthen the satisfaction of customers by understanding the customer spending habits and consumption (Hsiao et al., 2016).

Restaurant is a popular business venture in Indonesia because of the increasingly busy and hectic lifestyle in one of the factors for high consumptions (Cekindo Business International, 2019). As the capital of Indonesia, Jakarta has a lot of citizens identified as a millennial's generation (Profil Generasi Milenial Indonesia, 2018). Indonesian millennials have a hedonic lifestyle; and also they are looking for utilitarian value and prefer instant for everything, besides they are concerned and choose healthy food compared with fast foods (IDN Research Institute, 2020; Kang et al., 2015). The Bernstein (2018) stated despite growing richer, the millennials continue to dine out than prepared foods, and they allocated half of their income on dining and buying delicious food at the restaurants, because they have more purchasing power than baby boomers (Oyedele, 2018; Maloney, 2018; Markman, 2018). Restaurants selection could be influenced by food quality review and psychical environment of restaurants, the price of the meal or following the hype and looking for new experience anytime beside in the restaurant (Yates et al., 2017; Hlee et al., 2018). The way customers assess any information depends on whether customers are driven intrinsically (related to usefulness) or extrinsically (related to enjoyment) (Hlee et al., 2018).

Hedonic value relates to the information of enjoyment, satisfaction, and pleasure while utilitarian value is specified as functional benefit also integrates more cognitive aspects, such as cost-effectiveness, task-related and reasonable, convenience judgment, and time savings (Becker et al., 2019; Brown, 2018; Dagevos \& Ophem, 2013; Ha \& Jang, 2010; Park \& Nicolau, 2015; Yang et al., 2017). Customer perceived value is individual comparison of customer to identify be- 
tween the benefit and sacrifices or costs that customers paid and two types of customer perceived values are hedonic and utilitarian values (Ha \& Jang, 2010; Ryu et al., 2010; Ryu et al., 2012). The perceived hedonic value of customers is more subjective than utilitarian and typically require entertainment, and playfulness also the entire experience of excitement, perceived freedom, acquired feelings such as social, cognitive, and emotional (Kazakevičiūtė \& Banytè, 2013; Kim \& Han, 2011). Hedonic value of restaurants are related to buying regularity, buying intentions also still significantly influences customers' satisfaction ( $\mathrm{Ha} \&$ Jang, 2010; Ryu et al., 2010).

If customers perceive high values from experiences with consumption, they like to show positive behavior intentions (Ha \& Jang, 2010). Word-of-mouth is one of the strongest communication types in the service industry and has a positive and directly relate to customer satisfaction and behavior intentions ( $\mathrm{Ha} \&$ Jang, 2010; Han \& Ryu, 2009; Kim et al., 2009; Ryu et al., 2010; Ryu et al., 2012; Ryu \& Han, 2011). The intention to repatronize relates to the customer's emotional attachment, which reveals customer willingness to continue visiting also behavior intentions represent the probability of a customer to buy again and again (Atulkar \& Kesari, 2017). The Theoretical Framework for the study is based on the past study (Ha \& Jang, 2010; Ryu et al., 2010) which is the hedonic values and utilitarian values have an influence on customer satisfaction and customer satisfaction have an influence on behavior intentions. The researcher wants to know if the hedonic values and utilitarian values influence behavior intentions with the connection of customer satisfaction between the two.

This research is subjected to millennials because $24 \%$ of productive age in Indonesia are millennials and allocate their $8 \%$ of income for eating at the restaurants after family expenses and savings. In view of the increasing number of casual dining restaurants in Jakarta (Juniman, 2017; Kafe Dan Restoran Tumbuh Pesat, Pendapatan Stagnan, 2019; Melihat Peluang Bisnis Restoran di Jakarta, 2019), this study intends to inspect the relationship between hedonic and utilitarian values on satisfaction and behavior intention among casual-dining customers in Jakarta (IDN Research Institute, 2020). Restaurant industry is growing fast because its diversity ranges from high-end to low-end in Indonesia along with the majority of the market in Jakarta are millennials, therefore it is necessary to understand behavior intentions and satisfaction toward casual dining restaurants. The research addresses the research question: Do hedonic and utilitarian values in casual dining affect satisfaction and behavior intention of customers in Jakarta? By identifying the effect of hedonic and utilitarian values, investors, business owners and restaurant managers can have useful information and better understanding of millennials preferences to create effective promotional strategies and improve their position in the industry.

\section{Literature Review}

\section{Restaurant Industry in Indonesia}


In 2013 there were 380 million restaurant visits in Jakarta and reached revenues approximately USD \$1.5 Billion and the number of high end restaurants doubled between 2009 to 2014 also food service in Indonesia has a CAGR of 8.7 percent growth from 2010 to 2014, going up to USD $\$ 36.8$ billion sales in 2014 (Indonesia Investments, 2018). Casual dining is one of the types of full-services restaurants and usually delivers satisfying experiences, less intimidated than fine dining but higher than fast food also with affordable price (Cuca, 2019).

\section{Hedonic Value}

Hedonic value relates to the information of enjoyment, satisfaction, and pleasure (Becker et al., 2019; Park \& Nicolau, 2015; Yang et al., 2017). Perceived hedonic value of customers is more subjective than utilitarian and typically require entertainment, and playfulness also the entire experience of excitement, perceived freedom, acquired feelings such as social, cognitive, and emotional (Kazakevičiūtè \& Banytè, 2013; Kim \& Han, 2011). Hedonic value can be accomplished without purchasing a product or buying process (Kazakevičiūte \& Banyte், 2013; Kim \& Han, 2011). Hedonic value represents the customers buying process that could have a beneficial impact on the willingness to recommend and higher loyalty (Kazakevičiūtè \& Banytė, 2013). Meanwhile, Ha and Jang (2010) are also stated that restaurant customers have different dining out motivations, such as social life, enjoyment, flavorful, effectiveness, and economics and according to these motivations, diners also identify utilitarian value by evaluating food or service quality with the cash spent on food and facilities.

In addition, there is a relationship between customer feelings and hedonic value experienced during the buying process (Byun \& Mann, 2011). Therefore in restaurants, customers can have a sense of excitement, pleasure, and an experience is more important than just an out to eat (Brown, 2018). Restaurants add importance to the attractiveness of creating experiences more enjoyable and unique (Kuang et al., 2012). Customers do not just eat at restaurants out of emotions and feelings only, but desire linked to certain activities in restaurants. For these more interactive and memorable experiences, the person experiences emotions from certain offers (Kuang et al., 2012). Hedonic value of restaurants is related to buying regularity and buying intentions (Ha \& Jang, 2010; Ryu et al., 2010). Therefore the hypothesis will be:

$\mathrm{H1}$ : Hedonic value significantly and positively influence on customer satisfaction

\section{Utilitarian Value}

Utilitarian value obtained by a customer based on task-related and reasonable, such as eating out is affordable than cooking at home (Brown, 2018; Dagevos \& Ophem, 2013). Traditionally, utilitarian is functional, instrumental, and in natural cognitive mainly includes fulfilling the instrumental expectations that customers may have for the product or service and meaning to an end often equated with time, location and ownership requires rational intentions (Ryu et al., 2010). According to Ha and Jang (2010) “Restaurant customers have different eat- 
ing-out motivations, such as social interaction, fun, taste, effectiveness, economics and based on these motivations, by comparing food or service quality with the cash spent on food and facilities, diners often perceive utilitarian value". Motives for utilitarian restaurant patronage are positively related to buying intentions (Brown, 2018; Ha \& Jang, 2010; Kim, Jeon, \& Hyun, 2012; Ryu et al., 2010). Therefore the hypothesis will be:

H2: Utilitarian value significantly and positively influence on customer satisfaction

\section{Satisfaction}

Perceptions that exceed the expectations of a customer resulting chances of satisfaction, affecting in a good perspective towards the product or service and influencing future positive behavior intentions (Ha \& Jang, 2010). Customer experience has been used for measuring satisfaction, loyalty, and WOM (Yrjölä et al., 2019). The excellency of the product or the service that has been consumed is being compared to their perception with their expectations (Ha \& Jang, 2010). Dining satisfaction has affected post-dining behavior intentions and has a positive connection between customer satisfaction and mid-to-upscale restaurant behavior intentions (Ryu et al., 2012).

According to Harrington et al. (2012), Heung and Gu. (2012), and Yrjölä et al. (2019) studies has recognized a number of characteristics in the restaurant context that affect the customer satisfaction and experience such as neat and helpful personnel, restaurant atmospheric, location, parking space availability, food presentation, food quality, variety of the menu, price and portion size. According to Kim et al. (2009), customer satisfaction in dining activity was positively associated with return intention and positive word-of-mouth. Satisfaction is more likely to be affected by hedonic aspects than utilitarian aspects, which as an important role in creating loyalty and behavior intentions (Atulkar \& Kesari, 2017; Kuo et al., 2013; Thaichon \& Quach, 2015). Therefore, the hypothesis will be:

H3: Customer satisfaction significantly and positively influence on behavior intentions

\section{Behavior Intention}

Customers see high values from experiences with consumption. They tend to deliberate positive behavior intentions (Ha \& Jang, 2010). Word-of-mouth is a form of strong communication types in the service industry and has explicitly related between customer satisfaction and behavior intentions such as repurchasing (Ha \& Jang, 2010; Han \& Ryu, 2009; Kim et al., 2009; Ryu et al., 2010; Ryu et al., 2012; Ryu \& Han, 2011). Customers seek information and see word-of-mouth information more honest as the opinion of a third party based on their experiences during the information-seeking process (Ha \& Jang, 2010). The more emotional elements of a dining experience are appreciated by customers, the more they like the restaurant, they have more intention to fan out good word of mouth (Ha \& Jang, 2010). Hospitality researchers found the reasons for hedonic restaurant patronage are strongly correlated with buying fre- 
quency and intentions (Brown, 2018; Ha \& Jang, 2010; Ryu et al., 2010). The intention to repatronize relates to the customer's emotional attachment, which reveals customer willingness to continue visiting also behavior intentions represent the probability of a customer to buy again and again (Atulkar\& Kesari, 2017). Wang and Wu (2012) stated "customers usually buy and rebuy a product or service that can maximize their advantage" (Figure 1).

\section{Methodology}

\section{Measurement}

Researchers measured the relationship between hedonic and utilitarian values on satisfaction and behavior intention among casual-dining consumers in Jakarta with quantitative data and self-administered questionnaires consisting of five segments (hedonic value, utilitarian value, satisfaction, behavior intention, and socio-demographic). The questionnaires were randomly distributed to the millennials in Jakarta. A convenience sampling method was applied for this research. The questionnaire was designed based on a review of previous studies and was modified by the researcher based on a thorough literature review and was subsequently adjusted for content validity. This study used a five-point Likert scale ( $1=$ strongly disagree to $5=$ strongly disagree). The first segment of the questionnaire which contained five questions measured the hedonic values of the consumers (Ryu et al., 2010). The questions in this segment are: 1) I'm dining out at a casual dining restaurant because I could have a good feeling, 2) it was fun and enjoyable dining in a casual dining restaurant, 3) the dining experience at the casual dining restaurant was a real pleasure, 4) I felt the excitement of searching for food during the dining experience at the casual dining restaurant, and 5) Although the price was higher than fast food restaurants, I liked to eat out at a better place. The second segment of the questionnaire, which contained four questions, dealt with the utilitarian value of the customers (Ryu et al., 2010; Song \& Qu, 2017). The questions in this segment are: 1) it was convenient dining out in a casual dining restaurant, 2) it was pragmatic and economical dining out in a casual dining restaurant, 3) the food portion is sufficient to satisfy my hunger, and 4) I like casual dining restaurants because they make healthy food. The third segment consisted of three questions that measured customer satisfaction related to casual dining restaurants (Ryu et al., 2010; Ryu et al., 2012; Song \& Qu, 2017). The questions in this segment are: 1) the overall feeling I got from the casual dining restaurants was satisfied, 2) the overall feeling I got from

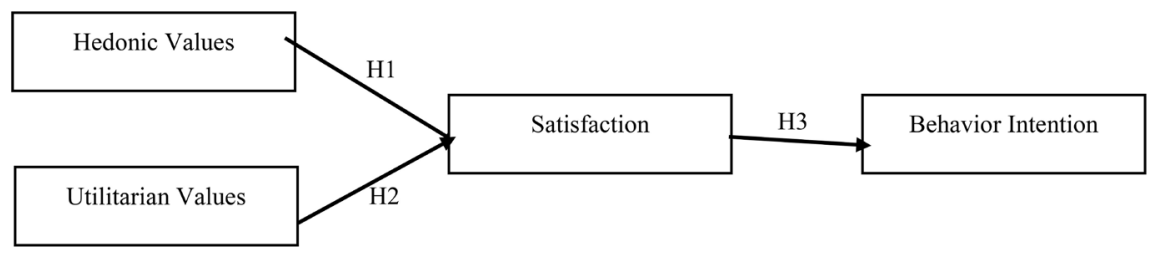

Figure 1. Theoretical Framework for the study. 
the casual dining restaurants put me in a good mood, and 3) I really enjoyed myself at the casual dining restaurants. The fourth segment consisted of three questions that measured the behavior intentions regarding casual dining restaurants (Ryu et al., 2012). The questions in this segment are: 1) I would like to come back to the casual dining restaurants in the future, 2) I would recommend casual dining restaurants to my family and friends, and 3) I would more frequently visit casual dining restaurants. The last segment was related to the socio-demographic profile of the correspondents, such as gender, occupation, monthly income, education, marital status, amount of spend in one time dining, and frequency of visit.

\section{Sampling and Data Collection}

Pilot test was conducted to 30 respondents who are in the range of age 20 - 35 years old who lives in Jakarta to test reliability and validity. Table 1 shows the constructs of the result for reliability test of Cronbach's alpha revealed that the instrument had a reliability factor above 0.6 which is interpreted as acceptable (Sekaran \& Bougie, 2016) (hedonic value $=0.851$, utilitarian value $=0.676$, customer satisfaction $=0.886$, and behavior intentions $=0.879$ ) while the result of the $\mathrm{KMO}$ and Bartlett validity test revealed that instrument had a validity factor above 0.5 (hedonic value $=0.731$, utilitarian value $=0.729$, satisfaction $=0.695$, and behavior intentions $=0.738$ ). All data processing was conducted by using SPSS version 22.0 (SPSS, Inc., Chicago, IL) to address the objectives of this study. The data was collected in January 2020 from 150 millennials in Jakarta through a web-based survey via Google Forms. Respondents were informed that they would be asked about their experience in casual dining restaurants in Jakarta. The socio-demographic profile of the correspondents, such as gender, occupation, monthly income, education, marital status, amount of spend in one time dining, and frequency of visit. The gender of the respondents is divided into 2 types such as, male and female. The occupations of respondents are divided into 5 categories such as students, employed, self employed, housewives, and unemployed. The monthly income (in Indonesian Rupiah) of respondents is divided into 5 categories such as less than 5 million, 5 - 10 million, 10 - 15 million, 15 - 20 million, and more than 20 million. The education of respondents is divided into 4 categories such as High School, Diploma I - III, Undergraduate and Postgraduate and above. The marital status of respondents is divided into 3 categories such as single, married, and divorce or widowed. The respondents' amount of spend in one time dining is divided into 3 categories such as less than 250.000, 250.001 - 500.000, and more than 500.000 in Indonesian Rupiah. The respondents' frequency of visit to casual dining restaurants is divided into 3 categories such as once a week, 2 - 3 times a week, and more than 3 times a week.

\section{Result and Discussion}

Table 2 shows the demographic profiles of respondents which is $69.3 \%$ of customers are females and $30.7 \%$ are males. The majority of respondents were em- 
ployees (77.3\%) followed by self employed (12\%), housewife (7.3\%), and students (3.3\%). Majority of the respondents had their monthly income between 5 until 10 Million Rupiah (46.7\%), the majority of respondents (78\%) were bachelor degree and most of them (62.7\%) were single. The majority of respondents (46\%) spent between IDR 250,001 to IDR 500,000 for one time in a casual dining restaurant. In terms of their frequency of visiting, the majority of them (70.7\%) went for at least once a week to casual dining restaurants.

Table 3 shows the structural relationship and hypothesis testing result of multiple linear regression $\left(R^{2}=73.9 \%\right)$ which is customer satisfaction had significant and positive relationship toward the hedonic value $(\beta=0.748, \rho=0.000)$ and also customer satisfaction had significant and positive relationship toward the utilitarian value ( $\beta=0.152, \rho=0.010$ ). The result of single linear regression showed that customer satisfaction had significant impact with positive effect toward the Behavioral Intentions $(\beta=0.804, \rho=0.000)$.

Table 1. Questionnaire and construct of reliability and validity.

\begin{tabular}{|c|c|c|}
\hline & Items & Loading \\
\hline \multicolumn{3}{|c|}{ Hedonic Values $($ Reliability $=0.851 ;$ Validity $=0.731)$} \\
\hline 1. & I'm dining out at a casual dining restaurant because I could have a good feeling. & 0.785 \\
\hline 2. & It was fun and enjoyable dining in a casual dining restaurant. & 0.607 \\
\hline 3. & The dining experience at the casual dining restaurant was a real pleasure. & 0.525 \\
\hline 4. & $\begin{array}{l}\text { I felt the excitement of searching for food during } \\
\text { the dining experience at the casual dining restaurant. }\end{array}$ & 0.819 \\
\hline 5. & $\begin{array}{l}\text { Although the price was higher than fast food restaurants, } \\
\text { I liked to eat out at a better place. }\end{array}$ & 0.923 \\
\hline \multicolumn{3}{|c|}{ Utilitarian Values (Reliability $=0.676$; Validity $=0.729$ ) } \\
\hline 1. & It was convenient dining out in a casual dining restaurant. & 0.691 \\
\hline 2. & It was pragmatic and economical dining out in a casual dining restaurant. & 0.858 \\
\hline 3. & The food portion is sufficient to satisfy my hunger & 0.770 \\
\hline 4. & I like casual dining restaurants because they make healthy food. & 0.973 \\
\hline \multicolumn{3}{|c|}{ Satisfaction (Reliability $=0.886$; Validity $=0.695)$} \\
\hline 1. & The overall feeling I got from the casual dining restaurants was satisfied. & 0.761 \\
\hline 2. & The overall feeling I got from the casual dining restaurants put me in a good mood. & 0.819 \\
\hline 3. & I really enjoyed myself at the casual dining restaurants. & 0.847 \\
\hline \multicolumn{3}{|c|}{ Behavior Intention (Reliability $=0.879$; Validity $=0.738$ ) } \\
\hline 1. & I would like to come back to the casual dining restaurants in the future. & 0.785 \\
\hline 2. & I would recommend casual dining restaurants to my family and friends. & 0.845 \\
\hline 3. & I would more frequently visit casual dining restaurants. & 0.994 \\
\hline
\end{tabular}


Table 2. Demographic details of respondents.

\begin{tabular}{|c|c|c|c|}
\hline \multicolumn{2}{|c|}{ Demographic characteristic } & \multirow{2}{*}{$\begin{array}{c}\text { Numbers } \\
46\end{array}$} & \multirow{2}{*}{$\begin{array}{c}\text { Percentage (\%) } \\
30.7\end{array}$} \\
\hline Gender & Male & & \\
\hline & Female & 104 & 69.3 \\
\hline \multirow[t]{5}{*}{ Occupation } & Student & 5 & 3.3 \\
\hline & Employed & 116 & 77.3 \\
\hline & Self Employed & 18 & 12 \\
\hline & Housewife & 11 & 7.3 \\
\hline & Unemployed & 0 & 0 \\
\hline \multirow[t]{5}{*}{ Monthly Income (Indonesian Rupiah) } & $<5$ Million & 26 & 17.3 \\
\hline & 5 - 10 Million & 70 & 46.7 \\
\hline & 10 - 15 Million & 30 & 20 \\
\hline & 15 - 20 Million & 16 & 10.7 \\
\hline & $>20$ Million & 8 & 5.3 \\
\hline \multirow[t]{4}{*}{ Education } & High School & 3 & 2 \\
\hline & Diploma I-III & 7 & 4.7 \\
\hline & Undergraduate & 117 & 78 \\
\hline & Postgraduate and above & 23 & 15.3 \\
\hline \multirow[t]{3}{*}{ Marital Status } & Single & 94 & 62.7 \\
\hline & Married & 56 & 37.3 \\
\hline & Divorce/Widowed & 0 & 0 \\
\hline Amount of Spend in one time Dining & $<250.000$ & 56 & 37.3 \\
\hline \multirow[t]{2}{*}{ (Indonesian Rupiah) } & $250.001-500.000$ & 69 & 46 \\
\hline & $>500.001$ & 25 & 16.7 \\
\hline \multirow[t]{3}{*}{ Frequency of Visit } & At least once a week & 106 & 70.7 \\
\hline & 2 - 3 times a week & 30 & 20 \\
\hline & More than 3 times a week & 14 & 9.3 \\
\hline
\end{tabular}

Table 3. Structural relationship and hypothesis testing result.

\begin{tabular}{cccccc}
\hline DV & IV & $R^{2}$ & Standard Coefficient & Sig. & $\propto$ \\
\hline Satisfaction & Hedonic Values & 0.739 & 0.748 & 0.000 & - \\
& Utilitarian Values & & 0.152 & 0.010 & - \\
& Satisfaction & 0.646 & 0.804 & 0.000 & - \\
\hline
\end{tabular}

The findings of this research showed that hedonic value and utilitarian value is affecting customer satisfaction and will lead to behavior intentions in casual dining restaurants among millennials. This research also found that millennials who live in Jakarta were spending IDR 250,001 to IDR 500,000 also has monthly income for 5 to 10 million rupiahs. The findings showed that millennials who 
live in Jakarta were spending $20 \%$ of their income to eat at the restaurant which is more than the data of Indonesia Millennials Report 2019 which showed that all millennials in Indonesia would like to spend $8 \%$ of the income to entertain themselves including eating at the restaurant. It is also shown that millennials who dine in casual dining restaurants are looking for hedonic and utilitarian value therefore further research is necessary to know which aspects of hedonic and utilitarian value in restaurants that are more attractive to millennials more.

\section{Conclusion}

The aim of this research is to understand behavior intentions and customer satisfaction toward casual dining restaurants among millennials. Based on the findings, this study found that hedonic value and utilitarian value affected customer satisfaction, which is the customer satisfaction positively affected behavior intentions of the customer. Millennials in Jakarta are willing to spend their 20\% of income for eating at the casual dining restaurant to entertain themselves and fulfil their social needs also to satisfy their hunger through good food with affordable price with fun experience. Millennials in Jakarta are still interested in dining in casual dining restaurants to have hedonic and utilitarian values to satisfy themselves as it will automatically impact their behavior intentions to rebuy towards casual dining restaurants. This study could be a useful reference for further research and improvement to customer satisfaction in the restaurant business industry in Jakarta and may extend to do in another type of restaurant. The study respondents were focused on millennials, the generation that is known as big spender than baby boomers. The millennials mostly spend their time on social media, which is sharing about their daily life, what they love and even what they eat, and their lifestyle was affected by trends at the moment. If the millennials found the casual dining restaurant satisfied their needs, the hedonic values of the millennials will likely make them capture and share it in their social media, and the utilitarian values will make them continue to visit the restaurants. Despite the hedonic and utilitarian values, the behavior intention of the satisfied millennials will be promoting casual dining restaurants to their family and friends. Business owners could use this research as based to make strategic plans for their business and restaurant managers could use this for this research to make a promotion, in order for other service sectors with new variables and concentrated findings.

\section{Conflicts of Interest}

The authors declare no conflicts of interest regarding the publication of this paper.

\section{References}

Atulkar, S., \& Kesari, B. (2017). Satisfaction, Loyalty and Repatronage Intentions: Role of Hedonic Shopping Values. Journal of Retailing and Consumer Services, 39, 23-34. 
https://doi.org/10.1016/j.jretconser.2017.06.013

Becker, S., Bräscher, A., Bannister, S., Bensafi, M., Calma-Birling, D., Chan, R. C., Wang, Y. et al. (2019). The Role of Hedonics in the Human Affectome. Neuroscience \& Biobehavioral Reviews, 102, 221-241. https://doi.org/10.1016/j.neubiorev.2019.05.003

Bernstein (2018). Shifting Balance of Power (180925113240). https://www.bernstein.com/Bernstein/EN_US/Research/Publications/Instrumentation/ ShiftingBalanceofPower.pdf

Brown, J. R. (2018). The Competitive Structure of Restaurant Retailing: The Impact of Hedonic-Utilitarian Patronage Motives. Journal of Business Research, 107, 233-244.

Byun, S., \& Mann, M. (2011). The Influence of Others: The Impact of Perceived Human Crowding on Perceived Competition, Emotions, and Hedonic Shopping Value. Clothing and Textiles Research Journal, 29, 284-297. https://doi.org/10.1177/0887302X11422820

Cekindo Business International (2019). Restaurant Market Experiencing Growth: Business Opportunity in Indonesia.

https://www.cekindo.com/blog/restaurant-market-experiencing-great-growth-opportu nity-in-indonesia

Cuca (2019). Casual Dining vs Fine Dining.

https://medium.com/@cucaflavormarketing/casual-dining-vs-fine-dining-51fe0e33b8d c

Dagevos, H., \& Van Ophem, J. (2013). Food Consumption Value: Developing a Consumer-Centred Concept of Value in the Field of Food. British Food Journal, 115, 1473-1486. https://doi.org/10.1108/BFJ-06-2011-0166

Díaz-Méndez, C., \& Van Den Broek, H. (2017). Eating Out in Modern Societies: An Overview of a Heterogeneous Habit. Appetite, 119, 1-4.

https://doi.org/10.1016/j.appet.2017.05.003

Ha, J., \& Jang, S. (2010). Perceived Values, Satisfaction, and Behavioral Intentions: The Role of Familiarity in Korean Restaurants. International Journal of Hospitality Management, 29, 2-13. https://doi.org/10.1016/j.ijhm.2009.03.009

Han, H., \& Ryu, K. (2009). The Roles of the Physical Environment, Price Perception, and Customer Satisfaction in Determining Customer Loyalty in the Restaurant Industry. Journal of Hospitality \& Tourism Research, 33, 487-510.

https://doi.org/10.1177/1096348009344212

Harrington, R. J., Ottenbacher, M. C., Staggs, A., \& Powell, F. A. (2012). Generation Y Consumers Key Restaurant Attributes Affecting Positive and Negative Experiences. Journal of Hospitality \& Tourism Research, 36, 431-449. https://doi.org/10.1177/1096348011400744

Heung, V. C., \& Gu, T. (2012). Influence of Restaurant Atmospherics on Patron Satisfaction and Behavioral Intentions. International Journal of Hospitality Management, 31, 1167-1177. https://doi.org/10.1016/j.ijhm.2012.02.004

Hlee, S., Lee, J., Yang, S., \& Koo, C. (2018). The Moderating Effect of Restaurant Type on Hedonic versus Utilitarian Review Evaluations. International Journal of Hospitality Management, 77, 195-206. https://doi.org/10.1016/j.ijhm.2018.06.030

Hsiao, Y., Chen, L., Chang, C., \& Chiu, F. (2016). Configurational Path to Customer Satisfaction and Stickiness for a Restaurant Chain Using Fuzzy Set Qualitative Comparative Analysis. Journal of Business Research, 69, 2939-2949.

https://doi.org/10.1016/j.jbusres.2015.12.063

IDN Research Institute (2020). Indonesia Millennial Report 2020: Understanding Millen- 
nials' Behaviours and Demystifying Their Stereotypes.

https://cdn.idntimes.com/content-documents/Indonesia-millennial-report-2020-by-ID N-Research-Institute.pdf

Indonesia Food Service Market (2020).

https://www.mordorintelligence.com/industry-reports/indonesia-foodservice-market

Indonesia Investments (2018). Outlook on the Food Service Industry in Indonesia. https://www.indonesia-investments.com/business/business-columns/outlook-on-the-fo od-service-industry-in-indonesia/item 9001

Juniman, P. (2017). Gaya Hidup Masyarakat Menjadikan Bisnis Kuliner Menjanjikan. https://www.cnnindonesia.com/gaya-hidup/20170118121405-262-187137/gaya-hidupmasyarakat-menjadikan-bisnis-kuliner-menjanjikan

Kafe dan Restoran Tumbuh Pesat, Pendapatan Stagnan (2019). https://www.jpnn.com/news/kafe-dan-restoran-tumbuh-pesat-pendapatan-stagnan

Kang, J., Jun, J., \& Arendt, S. W. (2015). Understanding Customers' Healthy Food Choices at Casual Dining Restaurants: Using the Value-Attitude-Behavior Model. International Journal of Hospitality Management, 48, 12-21. https://doi.org/10.1016/j.ijhm.2015.04.005

Kazakevičiūtè, A., \& Banytè, J. (2013). The Relationship of Consumers' Perceived Hedonic Value and Behavior. Engineering Economics, 23, 532-540. https://doi.org/10.5755/j01.ee.23.5.1975

Kim, B., \& Han, I. (2011). The Role of Utilitarian and Hedonic Values and Their Antecedents in a Mobile Data Service Environment. Expert Systems with Applications, 38, 2311-2318. https://doi.org/10.1016/j.eswa.2010.08.019

Kim, I., Mi Jeon, S., \& Sean Hyun, S. (2012). Chain Restaurant Patrons' Well-Being Perception and Dining Intentions. International Journal of Contemporary Hospitality Management, 24, 402-429. https://doi.org/10.1108/09596111211217888

Kim, W. G., Ng, C. Y., \& Kim, Y. (2009). Influence of Institutional DINESERV on Customer Satisfaction, Return Intention, and Word-of-Mouth. International Journal of Hospitality Management, 28, 10-17. https://doi.org/10.1016/j.ijhm.2008.03.005

Kuang, T., Huang, J. C., \& Chen, W. C. (2012). Starbucks Experiences Explored in Taipei. Journal of Human Resources and Adult Learning, 8, 107-116.

Kuo, N., Chang, K., Cheng, Y., \& Lai, C. (2013). How Service Quality Affects Customer Loyalty in the Travel Agency: The Effects of Customer Satisfaction, Service Recovery, and Perceived Value. Asia Pacific Journal of Tourism Research, 18, 803-822.

https://doi.org/10.1080/10941665.2012.708352

Maloney, G. (2018). 5 Trends Defining the Food and Beverage Industry, and Retail in General.

https://www.forbes.com/sites/gregmaloney/2018/04/10/five-trends-defining-the-food-a nd-beverage-industry-and-retail-in-general/\#7f32034a2b23

Markman, J. (2018). Feast on Millennials' Love of Restaurants. https://www.forbes.com/sites/jonmarkman/2018/07/30/feast-on-millennials-love-of-re staurants/\#31fbb635368

Melihat Peluang Bisnis Restoran di Jakarta (2019). https://www.stoqo.com/blog/527/melihat-peluang-bisnis-restoran-di-jakarta

Muñoz, F., Hildebrandt, A., Schacht, A., Stürmer, B., Bröcker, F., Martín-Loeches, M., \& Sommer, W. (2018). What Makes the Hedonic Experience of a Meal in a Top Restaurant Special and Retrievable in the Long Term? Meal-Related, Social and Personality Factors. Appetite, 125, 454-465. https://doi.org/10.1016/j.appet.2018.02.024

Oyedele, A. (2018). How Millennials Are Changing the Food Industry. 
https://www.inc.com/business-insider/millennials-food-industry-preferences-eating-ou t-restaurant-prepared-meals-catering.html

Park, S., \& Nicolau, J. L. (2015). Asymmetric Effects of Online Consumer Reviews. Annals of Tourism Research, 50, 67-83. https://doi.org/10.1016/j.annals.2014.10.007

Profil Generasi Milenial Indonesia (2018). Jakarta, Indonesia: Kementerian Pemberdayaan Perempuan dan Perlindungan Anak.

Research and Markets Ltd (2019.). Indonesia Foodservice Market-Growth, Trends and Forecasts (2019-2024).

https://www.researchandmarkets.com/research/m52nvx/the_indonesian?w=4

Ryu, K., \& Han, H. (2011). The Influence of Physical Environments on Disconfirmation, Customer Satisfaction, and Customer Loyalty for First-Time and Repeat Customers in Upscale Restaurants. International Journal of Hospitality Management, 30, 599-611. https://doi.org/10.1016/j.ijhm.2010.11.004

Ryu, K., Han, H., \& Jang, S. (2010). Relationships among Hedonic and Utilitarian Values, Satisfaction and Behavioral Intentions in the Fast Casual Restaurant Industry. International Journal of Contemporary Hospitality Management, 22, 416-432. https://doi.org/10.1108/09596111011035981

Ryu, K., Lee, H., \& Gon Kim, W. (2012). The Influence of the Quality of the Physical Environment, Food, and Service on Restaurant Image, Customer Perceived Value, Customer Satisfaction, and Behavioral Intentions. International Journal of Contemporary Hospitality Management, 24, 200-223. https://doi.org/10.1108/09596111211206141

Sekaran, U., \& Bougie, R. (2016). Research Methods for Business: A Skill Building Approach. John Wiley \& Sons.

Song, J., \& Qu, H. (2017). The Mediating Role of Consumption Emotions. International Journal of Hospitality Management, 66, 66-76. https://doi.org/10.1016/j.ijhm.2017.06.015

Spence, C., \& Piqueras-Fiszman, B. (2014). The Perfect Meal. The Multisensory Science of Food and Dining. Hoboken, NJ: John Wiley \& Sons. https://doi.org/10.1002/9781118491003

Thaichon, P., \& Quach, T. N. (2015). The Relationship between Service Quality, Satisfaction, Trust, Value, Commitment and Loyalty of Internet Service Providers' Customers. Journal of Global Scholars of Marketing Science, 25, 295-313. https://doi.org/10.1080/21639159.2015.1073419

Wang, C., \& Wu, L. (2012). Customer Loyalty and the Role of Relationship Length. Managing Service Quality: An International Journal, 22, 58-74.

https://doi.org/10.1108/09604521211198119

Yang, S., Hlee, S., Lee, J., \& Koo, C. (2017). An Empirical Examination of Online Restaurant Reviews on Yelp.com. International Journal of Contemporary Hospitality Management, 29, 817-839. https://doi.org/10.1108/IJCHM-11-2015-0643

Yates, D., Jodlowski, S., \& Court, Y. (2017). The Global Food and Beverage Market: What's on the Menu?

https://prch.org.pl/pl/baza-wiedzy/26-swiat/182-report-the-global-food-and-beveragemarket-what-s-on-the-menu-summer-2017-cushman-wakefield

Yrjölä, M., Rintamäki, T., Saarijärvi, H., Joensuu, J., \& Kulkarni, G. (2019). A Customer Value Perspective to Service Experiences in Restaurants. Journal of Retailing and Consumer Services, 51, 91-101. https://doi.org/10.1016/j.jretconser.2019.05.030

Yuen, E. F. T., \& Chan, S. S. L. (2010). The Effect of Retail Service Quality and Product Quality on Customer Loyalty. Database Marketing \& Customer Strategy Management, 17, 222-240. https://doi.org/10.1057/dbm.2010.13 